\title{
Aquatic community response to volcanic eruptions on the Ecuadorian Andean flank: evidence from the palaeoecological record
}

\author{
Frazer Matthews-Bird • Stephen J. Brooks • William D. Gosling • \\ Pauline Gulliver $\cdot$ Patricia Mothes $\cdot$ Encarni Montoya $(\mathbb{D}$
}

Received: 10 February 2017/ Accepted: 23 September 2017/Published online: 5 October 2017

(C) The Author(s) 2017. This article is an open access publication

\begin{abstract}
Aquatic ecosystems in the tropical Andes are under increasing pressure from human modification of the landscape (deforestation and dams) and climatic change (increase of extreme events and $1.5^{\circ} \mathrm{C}$ on average temperatures are projected for $\mathrm{AD}$ 2100). However, the resilience of these ecosystems to perturbations is poorly understood. Here we use a multi-proxy palaeoecological approach to assess the
\end{abstract}

Electronic supplementary material The online version of this article (doi:10.1007/s10933-017-0001-0) contains supplementary material, which is available to authorized users.

F. Matthews-Bird · W. D. Gosling · E. Montoya ( $\square$ ) School of Environment, Earth and Ecosystem Sciences, The Open University, Walton Hall, Milton Keynes MK7 6AA, UK

e-mail: emontoya@ictja.csic.es

F. Matthews-Bird

Department of Biological Sciences, Florida Institute of Technology, 150 West University Blvd, Melbourne,

FL 32901, USA

e-mail: matthewsbirdf@fit.edu

\section{S. J. Brooks}

Life Sciences, Natural History Museum, Cromwell Road, London SW7 5BD, UK

e-mail: S.Brooks@nhm.ac.uk

W. D. Gosling

Institute for Biodiversity and Ecosystem Dynamics

(IBED), University of Amsterdam, Postbus 94248,

1090 GE Amsterdam, The Netherlands

e-mail: W.D.Gosling@uva.nl response of aquatic ecosystems to a major mechanism for natural disturbance, volcanic ash deposition. Specifically, we present data from two Neotropical lakes located on the eastern Andean flank of Ecuador. Laguna Pindo $\left(1^{\circ} 27.132^{\prime} \mathrm{S}-78^{\circ} 04.847^{\prime} \mathrm{W}\right)$ is a tectonically formed closed basin surrounded by a dense midelevation forest, whereas Laguna Baños $\left(0^{\circ} 19.328^{\prime} S_{-}\right.$ $78^{\circ} 09.175^{\prime} \mathrm{W}$ ) is a glacially formed lake with an inflow and outflow in high Andean Páramo grasslands. In each lake we examined the dynamics of chironomids and other aquatic and semi-aquatic organisms to explore the effect of thick $(>5 \mathrm{~cm})$ volcanic deposits

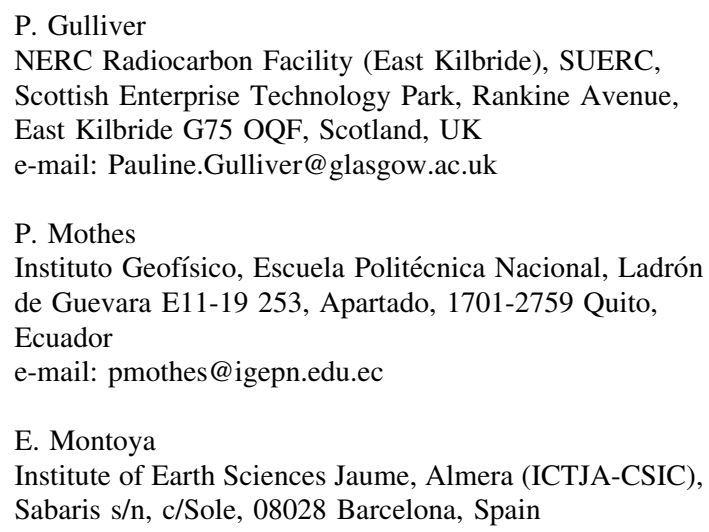


on the aquatic communities in these two systems with different catchment features. In both lakes past volcanic ash deposition was evident from four large tephras dated to c. 850 cal year BP (Pindo), and 4600, 3600 and 1500 cal year BP (Baños). Examination of the chironomid and aquatic assemblages before and after the ash depositions revealed no shift in composition at Pindo, but a major change at Baños occurred after the last event around $1500 \mathrm{cal}$ year BP. Chironomids at Baños changed from an assemblage dominated by Pseudochironomus and Polypedilum nubifer-type to Cricotopus/Paratrichocladius type-II, and such a dominance lasted for approximately 380 years. We suggest that, despite potential changes in the water chemistry, the major effect on the chironomid community resulted from the thickness of the tephra being deposited, which acted to shallow the water body beyond a depth threshold. Changes in the aquatic flora and fauna at the base of the trophic chain can promote cascade effects that may deteriorate the ecosystem, especially when already influenced by human activities, such as deforestation and dams, which is frequent in the high Andes.

Keywords Chironomids - Lake sediment burial · Long-term changes $\cdot$ Non-Pollen Palynomorphs (NPP) $\cdot$ Sensitivity $\cdot$ Tephras

\section{Introduction}

Explosive volcanic eruptions eject large amounts of silicate rock particles, known as tephra, into the Earth's atmosphere, which can eventually be deposited within the sediments of aquatic ecosystems. The environmental effects of tephra deposition, particularly on the benthic biota of the aquatic community, are difficult to quantify and are likely location specific (Telford et al. 2004). Modern monitoring studies have identified a detrimental effect of tephra on aquatic ecosystems after a volcanic eruption (Kurenkov 1966; Fazlullin et al. 2000; Collier 2002), however, often these studies do not cover a sufficient time frame to understand the lasting longterm effects on the aquatic communities (Telford et al. 2004). Furthermore, high impact rapid changes to the basal element of lacustrine food chains will have cascading consequences and may extend to the surrounding terrestrial ecosystem (Schulz et al. 2015). The palaeoecological record provides an opportunity to investigate the influence of volcanism on lake ecosystems both temporally, on long timescales (100-1000 years), and geographically across landscapes $\left(10-100 \mathrm{~km}^{2}\right)$. A more detailed understanding of the long-term effects of volcanism on aquatic habitats can help inform conservation and mitigation strategies. Here we use the palaeoecological record of two lakes to understand the long-term effects of volcanism in the high Andes, along the eastern Andean flank of Ecuador.

Tephra deposits can cause significant changes to lakes and their catchments (Eicher and Roundefell 1957; Baross et al. 1982; Hickman and Reasoner 1994; Zielinski 2000). The effects of tephra deposition can be both physical and chemical. Tephra will, in the short term, reduce light penetration due to the increased particulates in the water column (Abella 1988). An increase in sedimentation from either particulate settling or tephra erosion after a volcanic event may seal off the sediment-water interface, bury macrophytes, and prevent the recycling of nutrients such as phosphorus (Barker et al. 2000). Changes to lake chemistry can result from increased nutrient input from chemical weathering of tephra, and changes in lake water $\mathrm{pH}$ and salinity from siliceous deposition (Haberyan 1998; Telford et al. 2004). Whether physical, chemical, or both, volcanism has the potential to change aquatic ecosystems rapidly and cause regime shifts that could persist for hundreds of years (Hickman and Reasoner 1994; Barker et al. 2000).

Tephra input into a fresh water system is the result of either aeolian deposition or catchment erosion. The quantity of material ejected and its residence time within a catchment may determine the lasting effects of an event (Hickman and Reasoner 1994; Barker et al. 2000). As a result, certain lakes may be more sensitive than others and multiple sites may experience different consequences to similar or even identical events. Indeed, palaeoecological studies have shown a range of responses from aquatic communities to tephra deposition. Hickman and Reasoner (1994), in Canadian alpine lakes, noted a ten-fold increase in diatom concentrations lasting about 300 years after tephra deposition. By contrast other studies infer minor shortterm changes, from few years to just several days or even no direct response at all, to tephra deposition (Lotter et al. 1995; Telford and Lamb 1999; Self et al. 
2015). The response of a particular lake is difficult to predict and may differ between eruptions. For instance, a river-fed lentic ecosystem with a large catchment may receive a greater initial impact from a volcanic eruption than a closed basin (Telford et al. 2004), as more tephra is available to the former system from erosion into the habitat. On the other hand, riverfed habitats with a constant supply of fresh water may actually recover faster than closed basins as the tephra is not locked in the system and instead can be mobilised downstream or quickly replaced with fresh sediments brought in (Collier 2002). The size of the lake itself will also determine the lasting effect of a volcanic event since the effect of an eruption may be magnified in a small lake, as opposed to a larger setting (Barker et al. 2000).

Chironomidae, a diverse family of two-winged aquatic insects of the order Diptera (commonly known as non-biting midges), have long been used as freshwater quality indicators (Thienemann 1922) and have recently been used for palaeotemperature reconstructions in the tropical Andes (Matthews-Bird et al. 2016a). Chironomids inhabit a wide range of biotopes but most species are aquatic, few fresh water habitats do not support a chironomid population (Armitage et al. 1995). Chironomidae play a critical role within most aquatic food webs, they are a valuable source of food for other organisms, notably fish and birds, and are integral in the cycling of nutrients between primary and secondary consumers (Pinder 1986). Most species have been shown to be stenotopic and this, combined with rapid generational turnover (annual/sub-annual) and a mobile winged adult, means the family are extremely sensitive indicators of environmental change (Porinchu and MacDonald 2003).

Despite volcanism being a major feature of the Andes, little is known about the effects of volcanic activity on watersheds in the region. Here we use subfossil chironomid larvae to assess the long-term (centennial) effect of tephra deposition in two Andean flank lakes. The response of the chironomids is compared to the response of other aquatic communities occupying different trophic levels (autotrophs, mainly aquatic and littoral vegetation) from the same sediment sequence. Using the palaeoecological record, we assess the sensitivity and resilience of aquatic ecosystems to tephra deposition and the effects of light suppression, chemistry changes and burying. In addition, the potential influences of catchment features (e.g. openness of the landscape, water bodies' connectivity) are also considered.

Study sites

The Andean flank is a highly tectonic region, and experiences significant volcanic activity due to the continued convergence of the Nazca and Antarctic plates with the South American plate (Barberi et al. 1988). The Andean range is split into four volcanic belts: the Northern, Central, Southern and Austral Volcanic Zones. Both lakes analysed in this study lie within the direct influence of the Northern Volcanic Zone (NVZ) that spans northern Ecuador and Colombia (ESM1). Over 20 volcanoes are recognised as active across the NVZ both today and on Quaternary timescales (Hall et al. 2008). In this work, two lakes (Lagunas Pindo and Baños) have been selected based on their specific features: both are located at similar distances to active volcanoes, but greatly differ in the catchment characteristics and the exposure frequency to volcanic activity.

Laguna Pindo is a small shallow lake (1.2 m depth) and roughly circular in shape (around $40 \mathrm{~m}$ diameter) on the eastern Andean flank of Ecuador $\left(1^{\circ} 27.132^{\prime} \mathrm{S}-\right.$ $78^{\circ} 04.847^{\prime} \mathrm{W}$; Fig. 1). The site is located in Pastaza province near the town of Mera at an elevation of $1248 \mathrm{~m}$ a.s.l. Mean annual temperature is about $20^{\circ} \mathrm{C}$ with little seasonal variation, annual precipitation can reach up to $4000 \mathrm{~mm}$ per year (Hijmans et al. 2005). Currently the lake is not directly fed by an in-flow and has no visible out-flow (Fig. 1); the lake receives water from surface run-off and direct precipitation. Laguna Pindo is positioned in the Andean foothills on a steep slope dropping down to the Pastaza river basin, there are no obvious geomorphological causes for the escarpment of the lake and we hypothesize it is tectonic in origin. The lake is heavily overgrown with aquatic plants (Cyperaceae) and completely vegetated to the water's edge by a closed forest which surrounds the site with a canopy of 15-25 m high. The site lies within lower montane forest (Harling 1979) and dominant species belong to the families Melastomataceae, Araceae, Urticaceae (members of former Cecropiaceae), Euphorbiaceae, Myrtaceae, Rubiaceae, Myristicaceae, Asteraceae and Mimosoideae (Fabaceae). Lianas, epiphytes (Bromeliaceae, Orchidaceae), and tree ferns are also common. Laguna Pindo is approximately $40 \mathrm{~km}$ from Tungurahua, an andesitic-dactic stratovolcano and one of South America's most active (Fig. 1). Frequent ash 


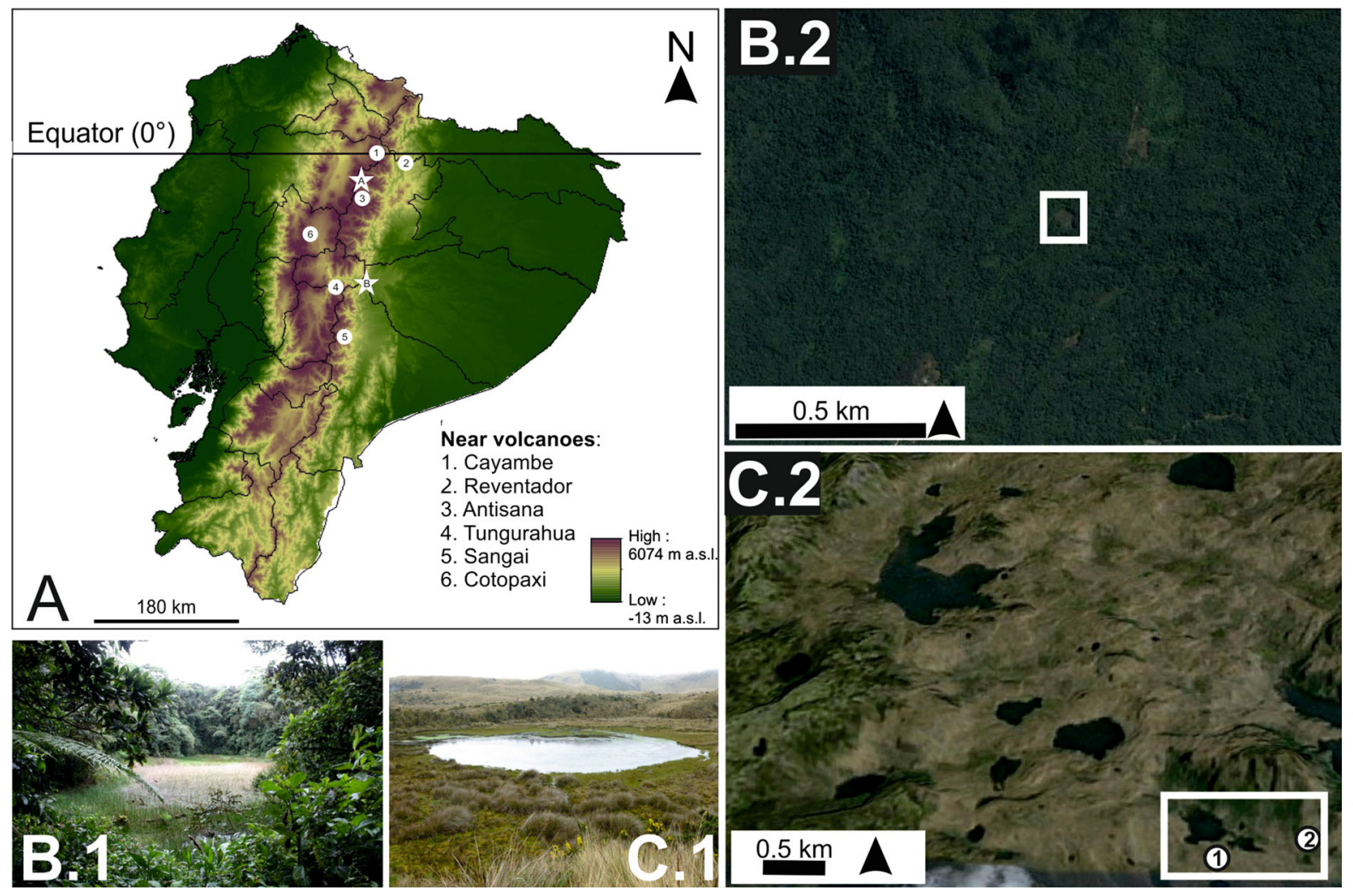

Fig. 1 a Map of Ecuador, showing location of the lakes studied (marked as stars: a Laguna Baños and b Laguna Pindo) and the main volcanoes close to the lakes (circles). b Laguna Pindo: Image of the lake (b.1), and Google Earth view of the catchment (b.2). c Laguna Baños: image of the lake (c.1), and Google Earth view of the catchment (c.2: numbers 1 and 2 indicate the water

explosions producing plumes several kilometres high, as well as pyroclastic flows, characterize Tungurahua (Hall et al. 1999; Le Pennec et al. 2008, 2013).

Laguna Baños is a small glacially formed lake $1 \mathrm{~m}$ deep, close to the town of Papallacta in the province of Napo on the eastern flank of the Ecuadorian Andes, situated at an elevation $3821 \mathrm{~m}$ a.s.1. $\left(0^{\circ} 19.328^{\prime} \mathrm{S}-\right.$ $78^{\circ} 09.175^{\prime} \mathrm{W}$; Fig. 1). The site is in a high lake district region of Cayambé Coca National Park, surrounded by Páramo vegetation (tropical alpine grassland). Mean annual temperature is about $5.7^{\circ} \mathrm{C}$ and mean annual precipitation is approx. $1300 \mathrm{~mm}$ per year (Hijmans et al. 2005). Although temperatures are almost constant throughout the year, daily variations can be $\sim 20{ }^{\circ} \mathrm{C}$ (Jørgensen and León-Yánez 1999). The lake is roughly circular (around $55 \mathrm{~m}$ in diameter) and is the last in a sequence of three lakes connected by a small stream (Laguna Baños system; Fig. 1). body analysed in Michelutti et al. (2016) and the present study respectively). Google Earth access on February 2016. Note the differences in the scale used for both images and in the openness of the catchment showed by colours in the online version $($ green $/$ dark $=$ forest; yellow $/$ light $=$ grassland $)$

Consequently, the lake receives water through inflow, surface run-off and direct precipitation. The site is currently heavily in-filled by aquatic plant and algal growth with a strong lotic influence. The surrounding vegetation is characteristic of grass Páramo, dominated by Calamagrostis sp. and Festuca sp. (Poaceae), with scattered patches of shrubby vegetation (Asteraceae) and mixed Polylepis sp. (Rosaceae) woodlands. Laguna Baños is about $19 \mathrm{~km}$ from the summit of Antisana (Fig. 1), a large stratovolcano, whose most recent activity was more than 1000 years before present and was of dacitic magmas (Hall et al. 2017).

\section{Materials and methods}

Sedimentary sequences 924 and $404 \mathrm{~cm}$ long were extracted from the deepest points of Lagunas Pindo 
and Baños, respectively, using a cam-modified Livingstone piston corer (Livingstone 1955; Colinvaux et al. 1999). Fourteen samples were selected from both cores and sent to the NERC Radiocarbon Facility, SUERC, East Kilbride, Scotland for radiocarbon analsysis by accelerator mass spectrometery (AMS) (Table 1). All samples underwent chemical pre-treatment to remove extraneous, contaminant carbon; full details of sample pre-treatment and conversion to graphite can be found in ESM2. Calibration was made with CALIB 7.0.4, and the IntCal13.14c database and SHCal.13.14c for Lagunas Baños and Pindo respectively (http://calib.qub.ac.uk./calib/, last accessed October 2015). Age-depth models were constructed using the statistical package clam in R (Blaauw 2010).

The composition of five tephra samples (one for $\mathrm{L}$. Pindo and four for L. Baños) were determined using X-Ray Fluorescence (XRF) Elemental determinations. XRF analysis was performed with an ARL $8420+$ dual goniometer wavelength dispersive XRF spectrometer at The Open University, UK. Analysis was run for major elements composition $\left(\mathrm{SiO}_{2}, \mathrm{TiO}_{2}\right.$,
$\mathrm{Al}_{2} \mathrm{O}_{3}, \mathrm{Fe}_{2} \mathrm{O}_{3}, \mathrm{MnO}, \mathrm{CaO}, \mathrm{Na}_{2} \mathrm{O}, \mathrm{K}_{2} \mathrm{O}$ and $\mathrm{P}_{2} \mathrm{O}_{5}$ ). Samples were recovered from the main inorganic layers found in both records. One tephra deposit was identified in Laguna Pindo (105-114 cm depth). The deposit had sandy texture, a greenish colour and included some decomposed and reworked plant material. Additionally, a sample from the inorganic sediment at the bottom of the sequence was also analysed (900 cm depth, not included in Fig. 2). Samples for XRF analysis from Laguna Baños were taken from thick tephra-like deposits (Table 2), corresponding to four intervals of highly compacted grey sediments of more than $5 \mathrm{~cm}$ thickness (Fig. 2).

A total of 56 samples $0.5 \mathrm{~cm}$ wide from both cores were analysed for chironomid remains, 32 samples at $10-16 \mathrm{~cm}$ intervals from Laguna Pindo, and 25 samples at 8-16 cm intervals from L. Baños. Analysis of sub-fossil chironomid larval head capsules followed standard methods (Brooks et al. 1997). Head capsules were dehydrated in $100 \%$ ethanol and mounted in Euparal dorsal side up. Specimens were identified to the highest taxonomic resolution under a light

Table 1 Conventional (yBP) and calibrated (cal yBP) Radiocarbon data used in construction of chronologies for Laguna Baños and Laguna Pindo

\begin{tabular}{lccccc}
\hline Publication code & Depth $(\mathrm{cm})$ & $\delta^{13} C_{\mathrm{VPDB}}(\%){ }^{*}$ & ${ }^{14} \mathrm{C}$ age $(\mathrm{yBP})$ & Calander age (cal year BP) $2 \sigma$ & Median age (cal year BP $)^{\mathrm{a}}$ \\
\hline Laguna Baños & & & & & 1090 \\
SUERC-50081 $^{\mathrm{b}}$ & 24 & -26.4 & $1219 \pm 35$ & $1061-1189$ & 1288 \\
SUERC-54389 $^{\mathrm{b}}$ & 40 & -24.7 & $1364 \pm 41$ & $1236-1346$ & 1357 \\
SUERC-43521 $^{\mathrm{b}}$ & 63 & -26.0 & $1457 \pm 36$ & $1299-1402$ & 1400 \\
SUERC-43524 $^{\mathrm{b}}$ & 98 & -23.5 & $1497 \pm 38$ & $1307-1420$ & 1615 \\
SUERC-43525 $^{\mathrm{b}}$ & 202 & -26.7 & $1721 \pm 38$ & $1552-1711$ & 3923 \\
SUERC-54393 $^{\mathrm{b}}$ & 312 & -25.3 & $3530 \pm 42$ & $3694-3920$ & 4887 \\
SUERC-50084 $^{\mathrm{b}}$ & 356 & -25.3 & $4308 \pm 37$ & $4832-4964$ & 6583 \\
SUERC-43526 $^{\mathrm{b}}$ & 402 & -27.3 & $5785 \pm 39$ & $6491-6671$ & 375 \\
Laguna Pindo & & & & & 849 \\
SUERC-54395 $^{\mathrm{c}}$ & 46 & -30.2 & $334 \pm 42$ & $289-470$ & 1878 \\
SUERC-47634 $^{\mathrm{c}}$ & 117 & -27.9 & $974 \pm 36$ & $769-923$ & 2283 \\
SUERC-47635 $^{\mathrm{c}}$ & 245 & -27.3 & $1973 \pm 39$ & $1812-1943$ & 2916 \\
SUERC-47569 $^{\mathrm{c}}$ & 329 & -24.9 & $2335 \pm 37$ & $2293-2361$ & 4342 \\
SUERC-47572 $^{\mathrm{c}}$ & 410 & -22.7 & $2829 \pm 39$ & $2781-2991$ & $4241-4447$ \\
SUERC-48854 $^{\mathrm{b}}$ & 461 & -28.7 & $3974 \pm 45$ & &
\end{tabular}

$* \delta^{13} \mathrm{C}$ values were measured on a dual inlet stable isotope mass spectrometer (Thermo Scientific Delta V Plus) and are representative of $\delta^{13} \mathrm{C}$ in the pre-treated sample material

${ }^{\mathrm{a}}$ Weighted average

${ }^{\mathrm{b}}$ Bulk sediment samples

'Wood remains' samples 

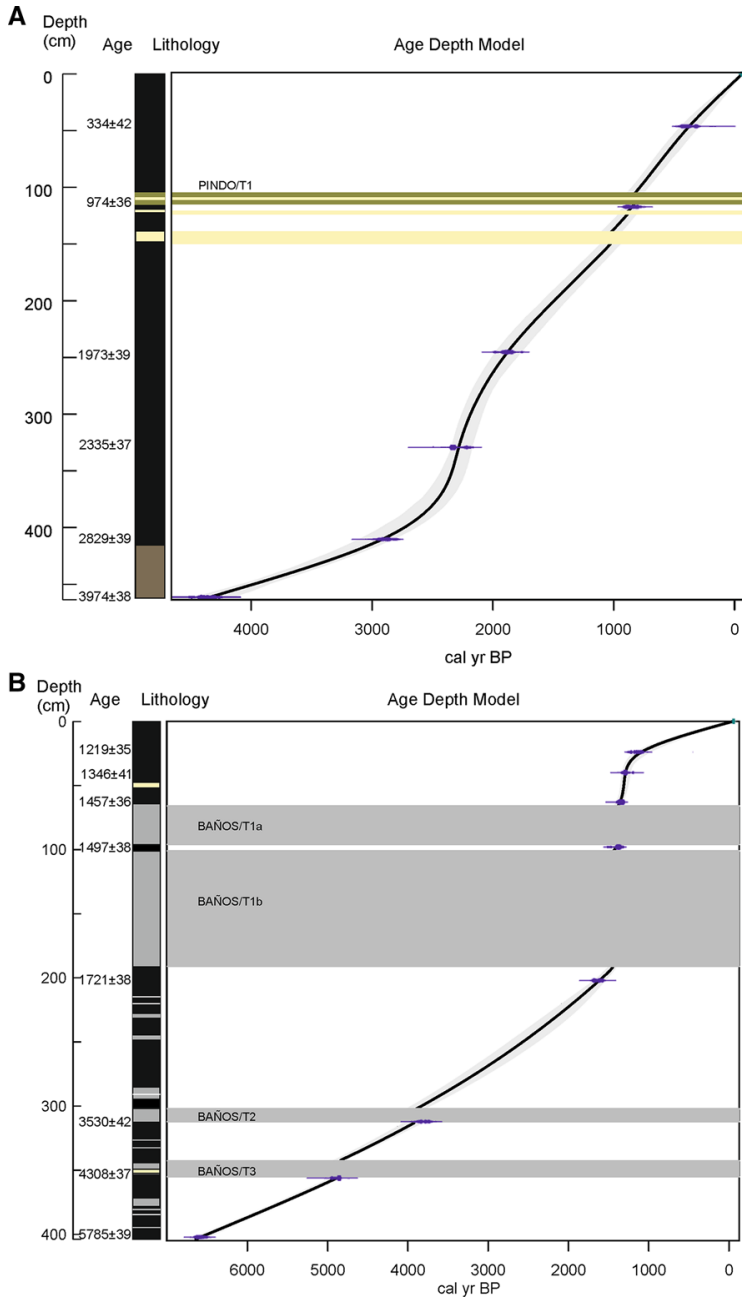

Fig. 2 Sediment lithology, radiocarbon dates (uncalibrated age), position of the tephras analysed (except PINDO/B) and age-depth models of a Laguna Pindo and b Pond Baños. Key colour for sediment descriptions in the online version: Black or dark brown $=$ organic rich sediments (peat, clay); white $=$ grey sandy intervals; grey $=$ compacted grey clay sediments (tephra); green = greenish sandy clay, not compacted; yellow $=$ sediment gap (no sediment)

microscope with reference to Wiederholm (1983), Brooks et al. (2007), and local taxonomic works including Prat et al. (2011), Trivinho-Strixino (2011), Williams et al. (2012) and Matthews-Bird et al. (2016b). Diagrams were plotted with PSIMPOLL 4.27 (Bennett 2009) and zonations were performed by "Optimal Splitting by Information Content" (OSIC), using the broken stick method to determine the significant zones (Bennett 1996).

Remains of aquatic and littoral vegetation, including aquatic and semi-aquatic pollen grains, fern spores, and algal and zoological remains other than chironomids, were also analysed. $1 \mathrm{cc}$ of wet sediment was processed from each of 63 samples (29 from Laguna Pindo, 10-20 cm sampling interval; and 34 from Baños, $10 \mathrm{~cm}$ interval), following standard palynological protocols (Faegri and Iversen 1989). Slides were mounted in glycerine jelly. Taxa abundances were expressed as percentage with respect to terrestrial pollen taxon sum. Identification was made according to Colinvaux et al. (1999), Hooghiemstra (1984), and Hooghiemstra and van Geel (1998). Diagrams were plotted with PSIMPOLL 4.27 (Bennett 2009) and the zones shown are the same as those used in the chironomid diagrams.

Detrended correspondence analysis (DCA) was performed using square root transformed percentage species assemblage data, as an indirect ordination method to assess the variation in species as compositional units of turnover. Statistical analysis was carried out in $\mathrm{R}$, using the package Vegan (Oksanen et al. 2013).

\section{Results \\ Chronology}

The best-fit age-depth model for L. Pindo was a smooth spline (Fig. 2). Six radiocarbon samples were used to date the sequence to $416 \mathrm{~cm}$. Below $416 \mathrm{~cm}$ chironomid head capsules were absent. The sedimentation rate ranged between 0.03 and $0.5 \mathrm{~cm}_{\text {year }}{ }^{-1}$, giving an average sampling interval of 97 years (range from 26 to 197 years). Average sampling resolution for the rest of the biological proxies was 99 years, ranging from 16 to 290 years.

Eight radiocarbon samples from L. Baños were used to produce a smooth spline age-depth model for the entire sequence (Fig. 2). The sedimentation rate ranged between 0.017 and $0.5 \mathrm{~cm}_{\text {year }}{ }^{-1}$, giving an average sampling interval of 282 years (range from 19 to 608 years). There was a marked variability in the sedimentation rate between the top and bottom sections of the Laguna Baños sequence that has resulted in different analysis resolution, due to sampling was carried out based on equidistant depths. In this sense, the average sedimentation rate of the upper (younger) $300 \mathrm{~cm}$ of the record resulted in around 200 years per sampling interval, whilst the resolution 
Table 2 Description of inorganic sediments sampled for XRF analysis and chemical composition based on the results obtained for the major elements (expressed in wt\%)

\begin{tabular}{|c|c|c|c|c|c|c|}
\hline Sample & $\mathrm{PINDO} / \mathrm{T} 1$ & PINDOB & BAÑOS/T1a & BAÑOS/T1b & BAÑOS/T2 & BAÑOS/T3 \\
\hline Sequence & Laguna Pindo & $\begin{array}{r}\text { Laguna } \\
\text { Pindo }\end{array}$ & $\begin{array}{l}\text { Laguna } \\
\text { Baños }\end{array}$ & $\begin{array}{l}\text { Laguna } \\
\text { Baños }\end{array}$ & $\begin{array}{l}\text { Laguna } \\
\text { Baños }\end{array}$ & Laguna Baños \\
\hline Depth & $105 \mathrm{~cm}$ & $887 \mathrm{~cm}$ & $93 \mathrm{~cm}$ & $161 \mathrm{~cm}$ & $307 \mathrm{~cm}$ & $348 \mathrm{~cm}$ \\
\hline $\begin{array}{l}\text { Tephra } \\
\text { thickness }\end{array}$ & $105-114 \mathrm{~cm}$ & $861-924 \mathrm{~cm}$ & $66-96 \mathrm{~cm}$ & $101-191 \mathrm{~cm}$ & $302-312 \mathrm{~cm}$ & $342.5-355 \mathrm{~cm}$ \\
\hline $\begin{array}{l}\text { Age (cal year } \\
\text { BP) }\end{array}$ & 825 & $>50,000$ & 1380 & 1470 & 3600 & 4625 \\
\hline Colour & $2.5 \mathrm{YR}-6 / 4$ & $2.5 \mathrm{YR}-6 / 1$ & $10 \mathrm{YR}-5 / 1$ & $10 \mathrm{YR}-5 / 1$ & $10 \mathrm{YR}-6 / 2$ & $10 \mathrm{YR}-5 / 1$ \\
\hline Texture & Sandy-silty sediment & Sandy clay & Clay & Clay & Clay & Sandy clay \\
\hline Compaction & $\begin{array}{l}\text { Not very compacted; reworked } \\
\text { plant material }\end{array}$ & $\begin{array}{l}\text { Highly } \\
\text { compacted }\end{array}$ & $\begin{array}{l}\text { Highly } \\
\text { compacted }\end{array}$ & $\begin{array}{l}\text { Highly } \\
\text { compacted }\end{array}$ & $\begin{array}{l}\text { Highly } \\
\text { compacted }\end{array}$ & $\begin{array}{l}\text { Highly } \\
\text { compacted }\end{array}$ \\
\hline $\mathrm{SiO}_{2}$ & 64.7 & 45.79 & 68.33 & 67.47 & 64.51 & 60.73 \\
\hline $\mathrm{TiO}_{2}$ & 0.31 & 1.814 & 0.295 & 0.31 & 0.356 & 0.516 \\
\hline $\mathrm{Al}_{2} \mathrm{O}_{3}$ & 15.46 & 36.76 & 14.9 & 15.31 & 16.14 & 17.36 \\
\hline $\mathrm{Fe}_{2} \mathrm{O}_{3}$ & 2.32 & 1.26 & 2.73 & 2.86 & 4.01 & 5.36 \\
\hline $\mathrm{MnO}$ & 0.054 & 0.008 & 0.06 & 0.061 & 0.075 & 0.093 \\
\hline $\mathrm{MgO}$ & 1.67 & 0.09 & 1.59 & 1.74 & 2.01 & 2.61 \\
\hline $\mathrm{CaO}$ & 2.99 & 0.11 & 2.81 & 3.15 & 4.34 & 5.99 \\
\hline $\mathrm{Na}_{2} \mathrm{O}$ & 4.24 & 0.05 & 4.4 & 4.6 & 4.33 & 4.08 \\
\hline $\mathrm{K}_{2} \mathrm{O}$ & 1.93 & 0.14 & 2.26 & 2.18 & 1.29 & 1.22 \\
\hline $\mathrm{P}_{2} \mathrm{O}_{5}$ & 0.189 & 0.104 & 0.115 & 0.124 & 0.159 & 0.149 \\
\hline LOI & 6.16 & 14.32 & 2.08 & 1.84 & 2.6 & 1.29 \\
\hline
\end{tabular}

Age expressed in calendar years before present (cal year BP). Colour has been estimated using Munsell Color Chart LOI loss of ignition

achieved in the bottom (older) $100 \mathrm{~cm}$ was almost of 500 years. Average sampling resolution for the rest of the biological proxies analysed was 214 years between samples, ranging from 24 to 565 years.

\section{Tephras}

Tephra is a much more common feature within the sedimentary sequence of L. Baños than in Laguna Pindo. In L. Baños, at least four large layers $(>5 \mathrm{~cm}$ thick) have been identified as possible tephra deposits whereas just one can be clearly observed in Laguna Pindo (Fig. 2).

XRF analysis of tephras shows a similar composition in major elements for all samples apart from the basal sample of L. Pindo (Sample PINDO B; Table 2), which is not a tephra. This can also be seen in the total alkali-silica (TAS) plot (Fig. 3). BAÑOS T1a and T1b are plotted together in the upper-right, to the left is the

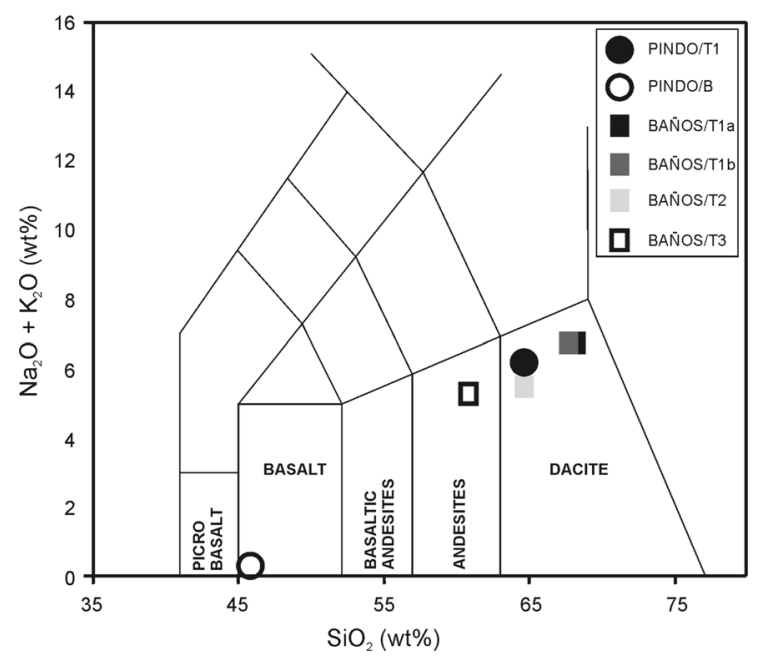

Fig. 3 Total alkali-silica (TAS) plot of the considered tephras following classification of Le Bas et al. (1986), and based on the results of Table 2 
only tephra found in L. Pindo (PINDO T1) and BAÑOS T2. All these samples are located within the dacite-composed domain. BAÑOS T3 is associated with the andesite-domain. PINDO/B is unlike any other sample and belongs to the basalt-domain. This result suggests the likely tectonic origin of the lake. Based on the XRF data (Table 2 and ESM3), ${ }^{14} \mathrm{C}$ dating chronology (Fig. 2) and visual examination of minerals contained in the inorganic sediments analysed (ESM4), we suggest that tephras BAÑOS T1a and BAÑOS T1b are from the same volcanic eruption (called BAÑOS T1), BAÑOS T1b being the original deposition and BAÑOS T1a a further input caused by either sediment collapse of the surrounding slopes or sediment arrival by inflow of upstream waters. The potential origin of tephra BAÑOS T1 could be from volcano Antisana (Hall et al. 2017), although other sources from the same volcanic district should not be ruled out (EMS3). Regarding the tephra found in Laguna Pindo (PINDO T1), a plausible source could be Tungurahua based on proximity and volcano activity. However, the dacitic nature of the ashes and the radiocarbon date obtained in the organic sediment below $(117 \mathrm{~cm})$, also supports a likely origin from the Quilotoa great eruption 800 cal year BP ago (Mothes and Hall 2008). Nevertheless, the suggestions about volcano sources of the tephras found are very preliminary and further analyses are required to confirm or reject both hypotheses.

\section{Chironomids}

\section{Laguna Pindo}

Chironomid remains were only found in the upper $414 \mathrm{~cm}$ (corresponding to the 32 samples used for this work) of the entire $924 \mathrm{~cm}$ sequence of Laguna Pindo. In total, 2461 individual chironomid head capsules (hc) were analysed. The entire assemblage included 45 taxa in 26 genera and 3 subfamilies. Among the taxa identified, 27 were Chironominae, 17 were Orthocladiinae and there was one Tanypodinae. Average head capsule concentration of samples between 0 and $200 \mathrm{~cm}$ (last 1500 year) was $106 \mathrm{hc} \mathrm{g}^{-1}$, compared with $44 \mathrm{hc} \mathrm{g}^{-1}$ from sediments below $200 \mathrm{~cm}$ (older than 1500 year BP).

Polypedilum nubifer-type, Procladius and Limnophyes were the most abundant taxa throughout the record ( $>10 \%$ wherever they occurred) (Fig. 4). Note the relationship in the observed trends between Polypedilum nubifer-type and Procladius and Tanytarsus I through the record. Based on major changes in chironomid assemblage composition revealed by zonation and DCA axis 1 scores, two significant zones were identified.

Zone PIN-A (200-414 cm) is characterised by a low concentration of hc and high abundance of Ceratopogonidae. Tanytarsus II is present throughout the zone but is at highest abundance in the lowermost part of the zone. The middle section is characterised by a decrease in Tanytarsus II, increase in Polypedilum nubifer-type and the first appearance in the record of Chironomus anthracinus-type. This is shortly replaced by an increased abundance of Procladius and Limnophyes. The uppermost part of this zone is dominated by Polypedilum nubifer-type, Tanytarsus-II, and Chironomini type II. The highest abundance of $\mathrm{Co}$ rynoneura cf. coronata-type is observed in this upper section too.

In Zone PIN-B $(0-200 \mathrm{~cm})$, the chironomid community shows a substantial change in its dominant taxa, with a dramatic decrease in Tanytarsus II and the appearance in a high abundance of other taxa barely represented in the previous zone, such as Chironomus anthracinus-type and Ch. plumosus-type. Compared to PIN-A, concentrations of chironomid hc and Ceratopogonidae are higher and lower respectively in this zone. Polypedilum nubifer-type, Ch. anthracinus-type and Beardius (absent from the majority of the sequence), peak around 160-200 cm (20\%), immediately after the beginning of the zone. The abundance of these last two taxa shortly declines and the upper section, before the tephra PINDO/T1, is dominated by Procladius, Limnophyes, and Tanytarsus I. This dominance continues after the tephra, together with the appearance of other taxa, although in less abundance, such as Ch. plumosus-type, Stempellina, and Chironomini type II. The upper section of the record is characterised by a generally decreasing trend in many taxa, except for P. nubifer-type and Procladius, and during the uppermost $20 \mathrm{~cm}, C h$. anthracinus-type and Ch. plumosus-type.

\section{Laguna Baños}

In total 725 chironomid hc were analysed from the sediments of L. Baños. The assemblage was made up of 18 different taxa in 4 sub-families: 7 Chironominae, 


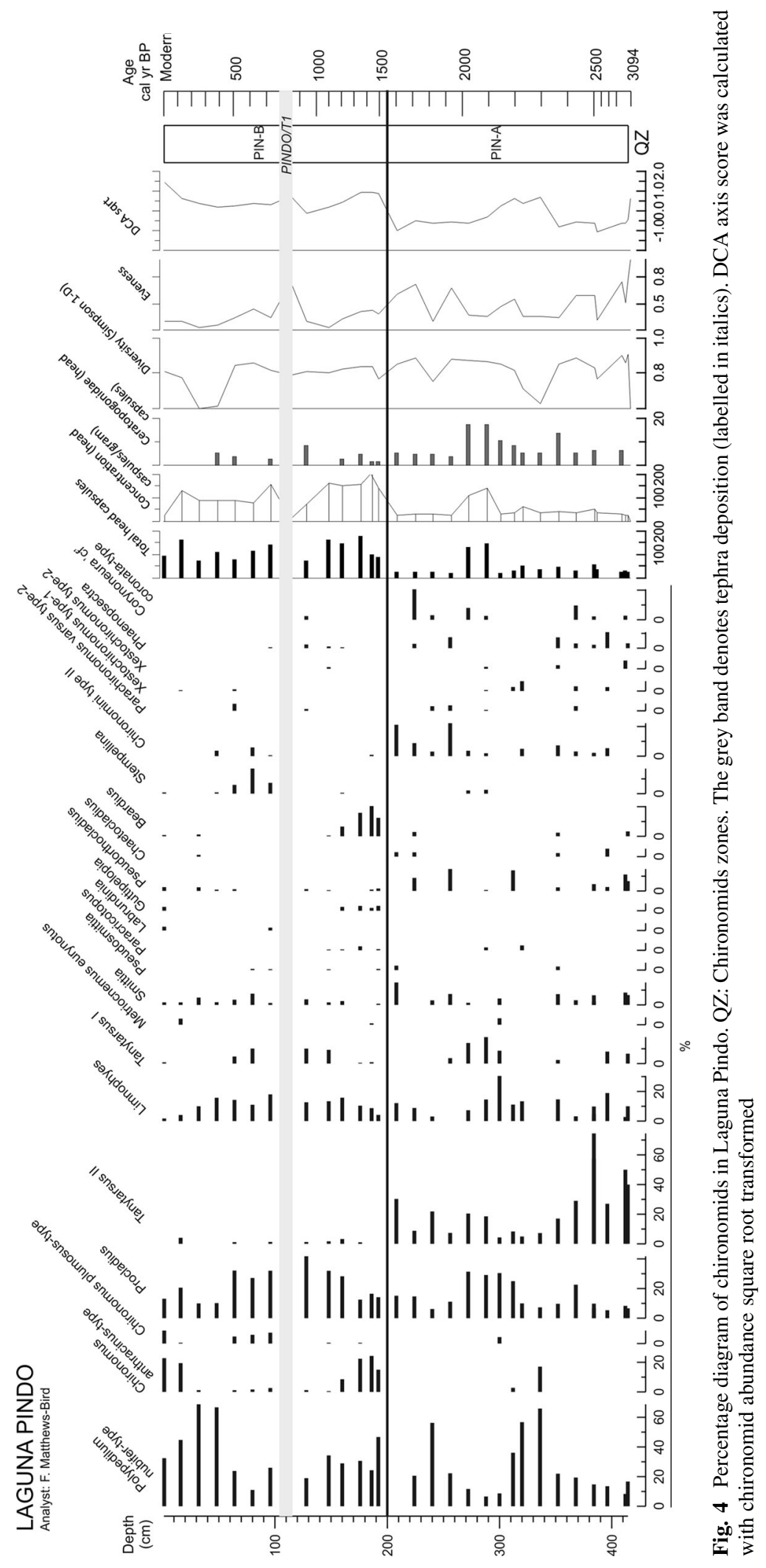


10 Orthocladiinae, and one Tanypodinae. Chironomid abundance varied throughout the sequence (average: $30 \mathrm{hc}$ per sample; range: 1 or $2-91 \mathrm{hc}$ ) as did concentration (average: 24 hc per gram; range: 1-69 hc); Ceratapogonidae was present in only two samples in the entire record. The three most dominant taxa throughout the record were Polypedilum nubifer type, Pseudochironomus and Cricotopus/Paratrichocladius type-II. Based on zonation analysis, two significant zones were established, separated by a large inorganic deposit (BAÑOS T1).

In Zone BAÑ-A (191-404 cm), Pseudochironomus dominates the assemblage (Fig. 5). The lowermost sample is also characterised by low abundances of Pseudorthocladius and Cricotopus/Paratrichocladius type-II. During intervals where Pseudochironomus slightly decreases in abundance, other Chironomini, such as Polypedilum nubifer type and Cricotopus/ Paratrichocladius type-II, increase. All other taxa occur only intermittently, including lentic morphotypes, such as Parachaetocladius, Thienemanniella and Rheotanytarsus, especially from around $270 \mathrm{~cm}$ upwards. The occurrence of taxa indicative of flowing waters coincides with low counts, low diversity and high evenness.

Zone BAÑ-B $(0-191 \mathrm{~cm})$ : Within the $90 \mathrm{~cm}$ deposits of tephra BAÑOS T1b and the $30 \mathrm{~cm}$ of T1a no chironomid remains were found. Above the tephra deposition the chironomid community is dominated by a completely different assemblage than previously (Fig. 5). The previous zone is dominated by Chironomini which is replaced by Orthocladiinae. Cricotopus/Paratrichocladius type-II, Limnophyes and Corynoneura cf. coronata-type are the most abundant taxa in this zone. Cricotopus/Paratrichocladius type-II is present in small numbers in earlier sediments (Zone BAÑ-A) but is present in high abundance after the tephra deposition. However, in the samples between 24 and $8 \mathrm{~cm}$ some components of the pre-eruption community partially return, although with very low values (Fig. 5). This assemblage pattern is also visible in the DCA biplot (ESM5). Sample 0 (uppermost sample) represents the modern assemblage and includes taxa such as Pseudosmittia and Parachironomus, not present in the assemblage before. This sample plots away from all other samples suggesting a different composition to anything previously recorded in the sequence.
Other aquatic biological proxies

The Laguna Pindo record is dominated by spores in zone PIN-A (Fig. 6), Monolete psilate being the most abundant taxon, and sporadic peaks of ferns, such as Monelete perine (T1 and T2), Tectaria and Trilete psilate T4. Polypodium verrucate have a continuous presence throughout the zone but with low abundances and bryophyte spores peak at the top of the zone (Fig. 6). PIN-B is characterised at first by an increase in Cyperaceae, that began to increase near the top of the previous zone, and a marked decrease in monolete psilate and a large increase in Polypodium verrucate. After the tephra deposit fern spores decrease in abundance and there is a peak in Cyperaceae abundance, which then rapidly returns to low values attained in zone PINA. Following this peak, there are increases in monolete psilate, Polypodium verrucate, Bryophytes and Sagittaria sp. The top of the zone is marked by the almost disappearance of Polypodium verrucate, and the sudden increase of an unknown fern and Botryococcus sp.

The sequence from L. Baños is also characterised by a dynamic record despite the lower number of taxa found. The first zone (BAN-A) is dominated by the aquatic fern Isoëtes sp. and the alga Pediastrum sp., followed by Monolete psilate, and Botryococcus to a lesser extent. The dominance of Isoëtes and Pediastrum in this zone is interrupted by the tephra deposits (Tephras BAÑOST2 and T3). Nevertheless, both taxa recover to former values after the inorganic deposits. Cyperaceae shows an increasing trend through this zone. Zone BAÑ-B shows a change in the community assemblage. Botryococcus, Cyperaceae and monolete psilate are the dominant elements, whereas Pediastrum and Isoëtes are present in lower abundances than in BAÑ-A. Neorhabdocoela sp. oocytes are also more abundant in this upper zone. The top sample is characterised by peaks in Botryococcus and Isoëtes, and, to a minor extent, Pediastrum, which show an increasing trend through the zone. 


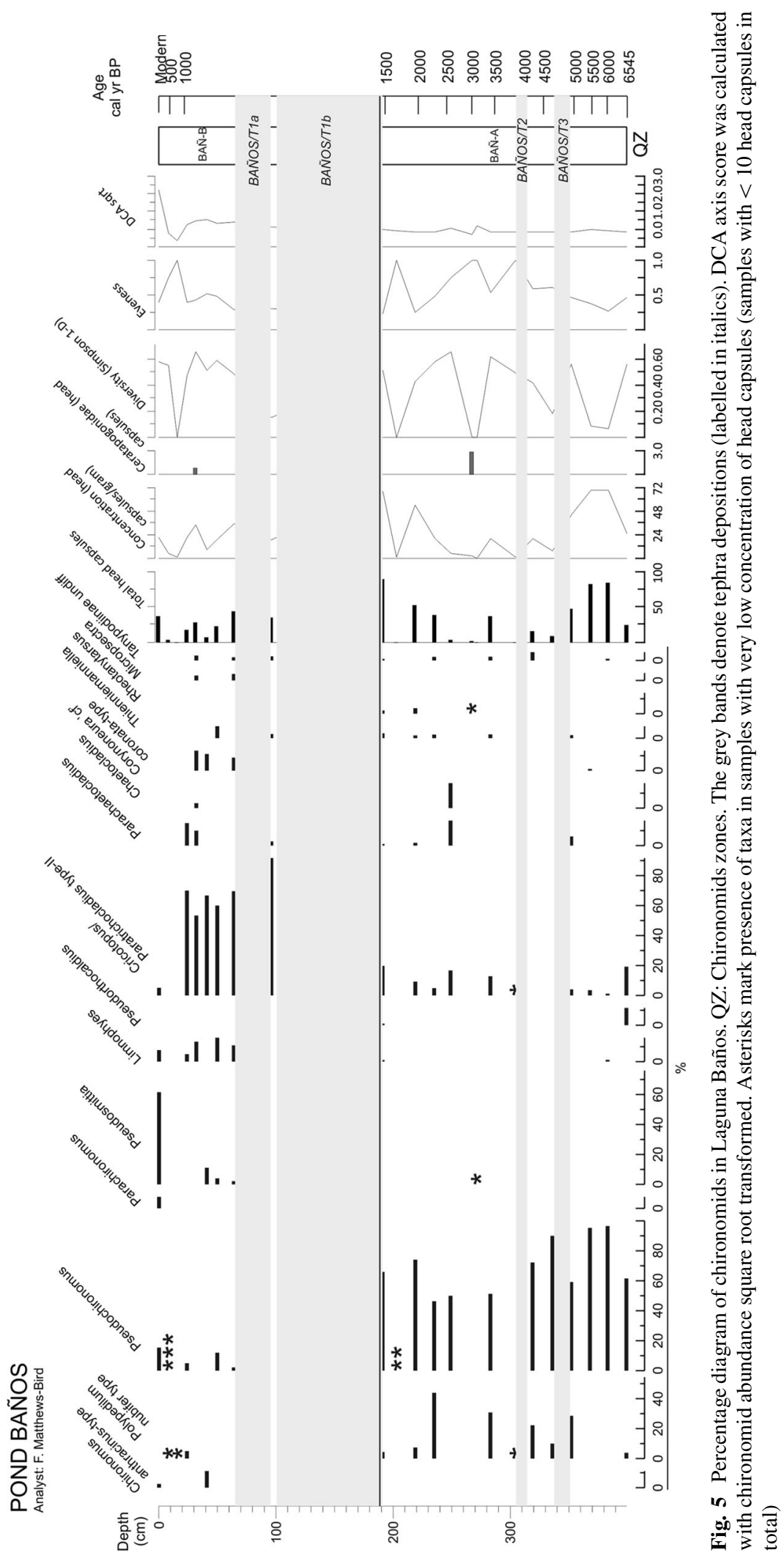




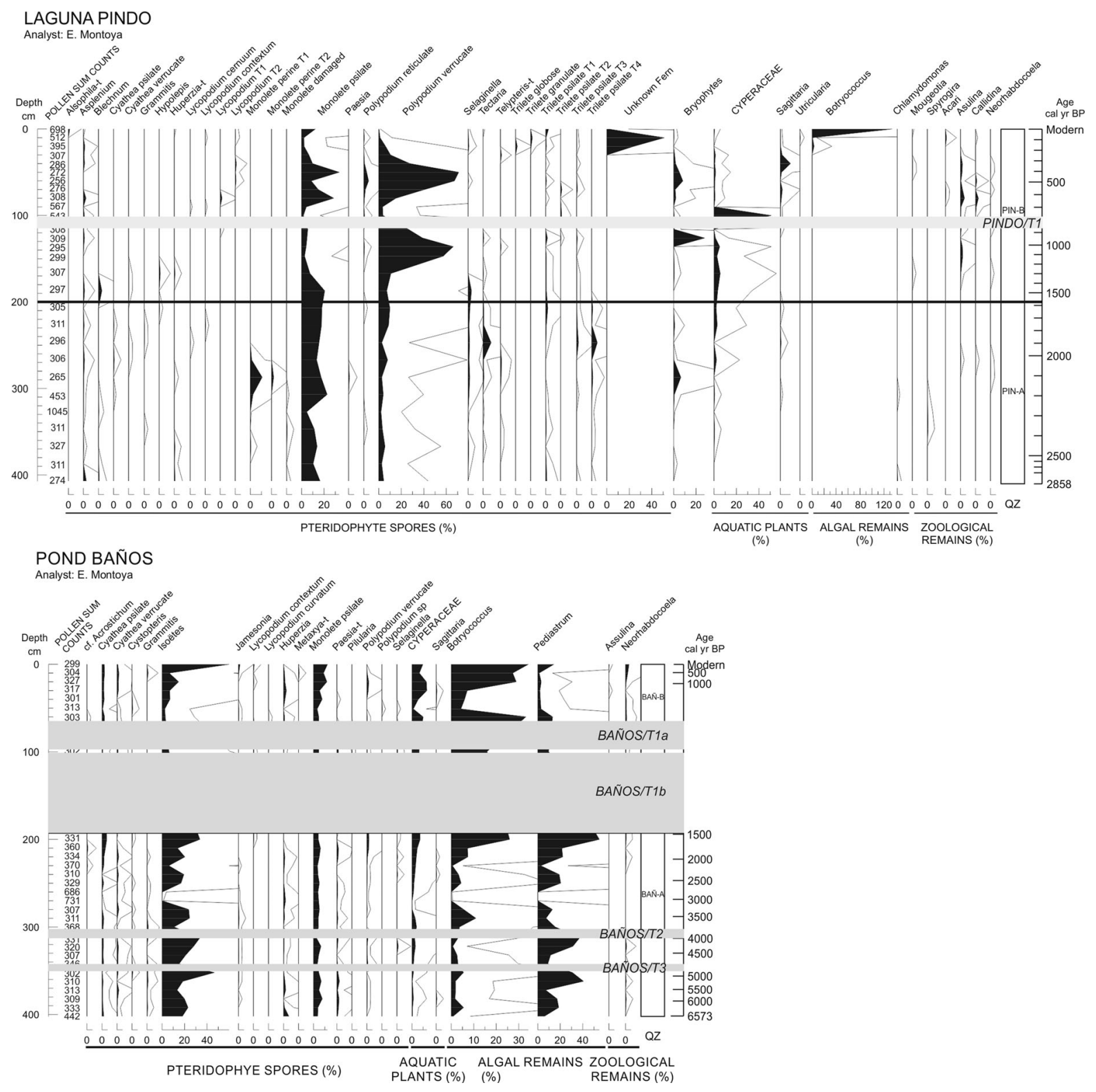

Fig. 6 Percentage diagrams (based on the sum of total terrestrial pollen, counts shown in the first column) of other aquatic communities (ferns, aquatic and semiaquatic plants,

\section{Discussion}

\section{Chemical effects}

The most conspicuous change in the aquatic community of the studied lakes was in L. Baños after the deposition of tephra BAÑOS T1. Pre-eruption assemblages (Zone BAÑ-A) are dominated by algae and other zoological remains other than chironomids) of the two sedimentary sequences studied. Grey bands indicate tephra deposits (labelled in italics)

Pseudochironomus whereas post-eruption assemblages are dominated by Cricotopus/Paratrichocladius type-II (Zone BAÑ-B). This taxon appears in high abundance even in the brief period between ash deposits BAÑOS T1a and T1b (Fig. 5). This result reflects findings in other records. For instance, Heinrichs et al. (1999) noted an increase in Cricotopus/ Orthocladius after deposition of the Mazama ash in 
Lake Kilpoola, British Columbia, whilst Araneda et al. (2007) noted a decrease in Pseudochironomus and an increase in Cricotopus/Orthocladius within the deposits of the 1956-1957 Llaima volcanic eruptions in Lake Galletue, Chile. These authors interpreted the changes to be the result of increased salinity caused by the volcanic deposition. Chemical weathering involves the solution of silica through leaching (Telford et al. 2004). Despite these similarities, our data differ from previous works as follows: i) the dominance of these taxa in previous studies was a short-lived feature (up to subcentennial), whereas in our record Cricotopus/Paratrichocladius-II dominates the assemblage for a longer period (around 380 years) after the ash deposit; and ii) the accumulation of the tephra causing those changes is much thicker in Baños (BAÑOS T1b: $90 \mathrm{~cm}+$ BAÑOS T1a: $30 \mathrm{~cm}$ ) than in other records $(<10 \mathrm{~cm}$, except for one tephra in Heinrichs et al. (1999) of around $30 \mathrm{~cm}$ thick) (Araneda et al. 2007; Telford et al. 2004). Such dominant deposits of tephra may not only directly affect the aquatic communities but may also cause instability and erosion of underlying mineral horizons in the catchment (Heinrichs et al. 1999). In this way, increased weathering from tephra deposition could lead to more Si being leached into the lake (Shoji et al. 1981; Telford et al. 2004), and therefore promote a sustained increase in salinity from increased erosion of mineral material over a long period. However, complementary analysis of another proxy sensitive to salinity, such as diatoms, would be essential to confirm this hypothesis. Michelutti et al. (2016) performed palaeolimnological analyses focused on diatom and chironomid assemblages in the most upstream water body of the Lake Baños system (Fig. 1) and showed that a volcanic ash deposit, likely corresponding to Tephra BAÑOS T1a, caused a spike in Hg concentration. This upstream Baños record did not extend prior to the large eruption, so comparisons between pre- and post-eruption assemblages or testing the salinity hypothesis remain elusive. However, field measures of conductivity differ in these two close water bodies, being upstream $58 \mu \mathrm{S} \mathrm{cm} \mathrm{cm}^{-1}$ (Michelutti et al. 2016) and downstream $194 \mu \mathrm{S} \mathrm{cm}{ }^{-1}$.

Alternatively, changes in chemistry following tephra deposition could be related to water acidification. Self et al. (2015) analysed the effect of Holocene volcanism in central Kamchatka (Beringia) based on pollen, diatom and chironomid analyses. The authors observed that richness of diatoms and chironomid species increased when $\mathrm{pH}$ increased during quiescent periods without volcanic activity, and suggested that lake biota were primarily responding to water chemistry changes driven by tephra impacts, whereas catchment vegetation was primarily responding to climate (Self et al. 2015).

\section{Physical effects}

Laguna Baños has more numerous and thicker tephra deposits than L. Pindo. The thicker deposits have a greatest impact upon chironomid communities, although the thinner deposits do result in subtle changes in evenness and diversity (tephras BAÑOS T2 and BAÑOS T3; Fig. 5). Accordingly to the minor tephra layers in Baños, there is no indication of a major shift in chironomid assemblages after the eruption at Laguna Pindo either (Zone PIN-B; Fig. 4). At L. Baños a change in the assemblages of other proxies before and after the deposition of the tephra BAÑOS T1 (Fig. 6) is also apparent. The littoral plant community occurring before the BAÑOS T1 deposit is characterised by taxa indicative of clean, oligotrophic waters, and the high abundance of the aquatic fern Isoëtes suggests the lake was relatively deep (Gosling et al. 2008). In the upper section of the record (after the tephra deposition) a decrease in those taxa and an increase in generalist algae (including those occurring in eutrophic waters) and Cyperaceae, suggest that the lake has become shallower (Gosling et al. 2008; Montoya et al. 2010). In Laguna Pindo, the only marked change observed in the aquatic vegetation is the sudden peak of Cyperaceae just after the tephra deposit, suggesting an ephemeral increase in the littoral zone or opening of the terrestrial vegetation. However, in this case the taxon returned to previous abundance in the next sample above.

Moreover, in Laguna Pindo the sediment associated with the tephra layer was characterised by a noncompacted material and contained some chironomid remains. BAÑOS T1, by comparison, is composed of very compacted sediment and no chironomid remains. In the study made in the L. Baños system by Michelutti et al. (2016), the post-tephra chironomid community was similar to the one we observed. The authors also highlighted the thickness and compaction of the ash deposit found. Such a compact, indurated deposit prevented the recovery of the full length of the tephra 
and the sediment below it, as well as the study of the aquatic communities present in the water body prior the tephra event (Michelutti et al. 2016). This compacted layer would have buried the benthic communities and limited bioturbation. In our data, the only observed change in pelagic autotrophic organisms corresponds to the decrease in Pediastrum observed in the upper section of L. Baños (Fig. 6). The results suggest that the effect of the tephra on the chironomid community is likely physical, as the thickest tephra deposit has greatest impact. This suggestion is not just based on the comparison between the most recent tephras at Pindo and Baños, but also between different tephras at Baños, where the thinner tephra layers have less impact even though they have similar chemical composition (Table 2 and ESM3; Fig. 3). Both chironomids and other aquatic organisms show a similar response, in which the older (thinner) tephras at Baños caused negligible impact on the community but the large tephra deposit resulted in a regime shift, indicated by a marked and sustained assemblage turnover. Based on the available evidence presented here, we suggest that this shift is related to a substantial shallowing of the lake produced by the deposition of a $>1 \mathrm{~m}$ thick ash layer, which considering that the lake is today about $1 \mathrm{~m}$ deep, could have potentially halved the depth of the lake at the time of the deposition. This hypothesis is supported by the increase of littoral Orthocladiinae taxa in Zone BAÑB. Thus, the profound change in the bathymetry of the water body basin is a major driver of the long-term assemblage shift, causing a loss of resilience of the community after a threshold event (Seddon et al. 2014; Hodgson et al. 2015).

The recovery of such a thick volcanic deposit as BAÑOS T1 in a sedimentary archive is unusual. As already mentioned, most of the previous studies analyse the effects of thin tephras upon the catchment or lake system, and any changes reported in the biota are often short-term. Besides burial, the immediate consequence to aquatic communities of tephra deposition is reduced light availability which is detrimental to aquatic macrophytes and photosynthetic algae (Abella 1988). Tephra settling velocity, however, is fast $\left(>40 \mathrm{~m} \mathrm{~h}^{-1}\right)$ and is unlikely to account for ecological responses of $>1$ year (Telford et al. 2004). None of the present records have provided evidence to support light suppression of the aquatic flora following the ash deposition (Fig. 6), maybe because the temporal resolution is too coarse considering the rapid biological cycle of the pelagic algal taxa involved.

\section{Catchment features' effects}

The two sites in our study have very different catchments. Laguna Pindo is completely vegetated with dense canopy forest and no river inflow. In contrast, Laguna Baños is in an open grassland landscape with areas of bare rock and is the last in a series of water bodies connected by a stream (Fig. 1). The exposed landscape around L. Baños is perhaps the reason it seems to be much more sensitive to the effects of a volcanic eruption. The tephra deposits in Baños are more numerous and larger than in Laguna Pindo probably because more material can enter the lake due to the open landscape and the cascading effect of being downstream of tephra sinks. On the other hand, the lower amount of tephra deposited in PINDO T1 would have been influenced by the nearness of erupting dacitic volcanoes and the physical barrier of the forested surroundings (Fig. 1). Related to this could also be the different provenance of the volcanic deposits. Whereas Laguna Pindo only received one thin tephra, L. Baños received many volcanic deposits, coming potentially from at least two different sources (ESM4). Besides vegetation cover, wind direction is a major driver in the amount of ash arriving in both landscapes, but also L. Baños is located nearer to large young dacite eruptive centers such as Antisana and Guagua Pichincha (Hall et al. 2008, 2017), "Cosanga volcanoes". On the other hand, as L. Baños is river-fed, the lake can receive ash over long periods from the catchment, whereas L. Pindo is fed only by precipitation. This is reflected in the sensitivity of the chironomid assemblages of the Laguna Baños system, in which the upstream assemblage is more stable (Michelutti et al. 2016) than downstream assemblage.

Finally, it is also important to consider human landuse practices altering the surrounding landscape, which may increase the lake's vulnerability to an eruption. Humans have occupied the Andes since the early Holocene (Rademaker et al. 2014), however, evidence for sustained and high intensity manipulation of the landscape does not appear until after 4000-3000 cal year BP (Chepstow-Lusty et al. 2011). The modern treeline occurs around $3200 \mathrm{~m}$ a.s.l., however, in the absence of humans, it is thought 
to lie closer to $3900 \mathrm{~m}$ (Ellenberg 1958; Kessler 1995). Deforestation can modify the catchment area and therefore may increase the sensitivity of high Andean lake ecosystems to volcanic eruptions. Deforestation (and hence, erosion) facilitates the in-wash of higher amounts of ashes into the aquatic system. Dams may have similar effects by compacting and thickening the tephra held in a dammed lake. The sensitivity of high altitude lakes is particularly important, as L. Baños is located within the Cayambé Coca National Park, which is the main water supply for the Metropolitan District of Quito and surrounding areas ( $>1.5$ million of people) (Echavarría and Lochman 1998). Another human impact is eutrophication, which can affect water quality. The uppermost samples of L. Pindo are characterised by the presence of Chironomus anthracinus and Ch. plumosus and a decrease in Tanytarsus-II, and dense aquatic vegetation suggesting the potential effect of recent eutrophication. Whether the recent eutrophication is naturally forced by lake infilling or is human-induced cannot be discerned, however, without further analysis.

\section{Conclusions}

Volcanism has been a constant feature of Quaternary environments in the tropical Andes. Combined with on-going climate change and human land use practices, however, high impact volcanic events have the potential to radically alter Andean aquatic ecosystems. Our data suggest that tephra thickness (i.e., the amount of ashes deposited within a system) is the most important factor determining the lasting impact of an eruption on the chironomid community. Tephra thickness is particularly important in shallow systems, as it will dramatically change the bathymetry and may result in an ecological threshold being crossed. The impact of tephra deposition can be magnified by catchment features such as the water bodies' connectivity and extent of vegetation cover. Laguna Pindo, which has a small, non-connected, catchment and is heavily forested to the water's edge, is buffered from long-term impacts caused by an eruption. Laguna Baños, in contrast, is more exposed to long-term effects of a high impact event and thus more sensitive. It is also located closer to volcanoes that produce large silica-rich ash volumes. Chemical effects, which are also dependent on the amount of tephra deposited, may also contribute to the amount of change in the aquatic communities. Finally, the intensity of human land-use practices, such as deforestation and damming, may magnify these impacts by allowing rapid deposition of large amounts of tephra and decreasing the resilience of the systems to change. A better understanding of ecosystem sensitivity and resilience to high impact events can help guide mitigation strategies and conservation policy. The palaeoecological record provides a framework for identifying key elements of ecosystems resilience. More empirical data on disturbance to aquatic communities caused by volcanic ash deposits, such as light suppression, chemical stress or physical burying, is required.

Acknowledgements This study has been developed under the auspices of project FORSENS, funded by the Natural Environment Research Council UK (Grant NE/J018562/1 to E. Montoya). Radiocarbon dating was supported by the NERC Radiocarbon Facility NRCF010001 (allocation number 1682.1112) awarded to FORSENS project Permits for fieldwork in Ecuador were provided by the Ministry of Environment, Ecuador (14-2012-IC-FLO-DPAP-MA). Special thanks to John Watson and Emily Sear for the technical support at The Open University. Hayley Keen designed the Ecuador map and plotted the TAS diagram, and Joseph J Williams and Macarena Cárdenas participated in the field work. The comments of two anonymous reviewers and editors Thomas $\mathbf{J}$ Whitmore and Jaime Escobar greatly improved the quality of the manuscript.

Open Access This article is distributed under the terms of the Creative Commons Attribution 4.0 International License (http:// creativecommons.org/licenses/by/4.0/), which permits unrestricted use, distribution, and reproduction in any medium, provided you give appropriate credit to the original author(s) and the source, provide a link to the Creative Commons license, and indicate if changes were made.

\section{References}

Abella SE (1988) The effect of the Mt. Mazama ashfall on the planktonic diatom community of Lake Washington. Limnol Oceanogr 33:1376-1385

Araneda A, Cruces F, Torres L, Bertrand S (2007) Changes of sub-fossil chironomid assemblages associated with volcanic sediment deposition in an Andean lake (38 $\left.{ }^{\circ} \mathrm{S}\right)$, Chile. Rev Chil Hist Nat 80:141-156

Armitage PD, Cranston PS, Pinder LC (1995) The Chironomidae: the biology and ecology of nonbiting midges. Chapman and Hall, London

Barberi F, Coltelli M, Ferrara G, Innocentii F, Navaro J, Santacroce R (1988) Plio-quaternary volcanism in Ecuador. Geol Mag 125:1-14 
Barker P, Telford R, Merdaci O, Williamson D, Taieb M, Vincens A, Gibert E (2000) The sensitivity of a Tanzanian crater lake to catastrophic tephra input and four millennia of climate change. Holocene 10:303-310

Baross JA, Dahm CN, Ward AK, Lilley MD, Sedell JR (1982) Initial microbiological responses in lakes to the Mt. St. Helens eruption. Nature 296:49-52

Bennett KD (1996) Determination of the number of zones in a biostratigraphical sequence. New Phytol 132:155-170

Bennett KD (2009) "psimpoll" and "pscomb": C programs for analysing pollen data and plotting pollen diagrams (version 4.27). Queen's University Belfast. http://www.chrono.qub. ac.uk/psimpoll.html

Blaauw M (2010) Methods and code for "classical" age-modelling of radiocarbon sequences. Quat Geochronol 5:512-518

Brooks SJ, Lowe J, Mayle FE (1997) The Late Devensian Lateglacial palaeoenvironmental record from Whitrig Bog, SE Scotland. 2. Chironomidae (Insecta: Diptera). Boreas 26:297-308

Brooks SJ, Langdon PG, Heiri O (2007) The identification and use of Palaearctic Chironomidae larvae in palaeoecology. QRA Technical Guide No. 10, Quaternary Research Association, London

Chepstow-Lusty AAJ, Bennett KD, Fjeldså J, Kendall A, Galiano W (2011) 4000 years of environmental history in the Cuzco Area, Peru, from the pollen record. Mt Res Dev 18:159-172

Colinvaux PA, De Oliveira PE, Moreno JE (1999) Amazon pollen manual and atlas. Harwood Academic Publishers, Amsterdam

Collier KJ (2002) Efects of flow regulation and sediment flushing on instream habitat and benthic invertebrates in a New Zealand river influenced by a volcanic eruption. River Res Appl 18:213-226

Echavarría M, Lochman L (1998) Watershed conservation fund in Quito, Ecuador. Policy mechanisms for watershed conservation: case studies. Washington, DC, TNC

Eicher G, Roundefell G (1957) Effects of lake fertilization by volcanic activity on abundance of salmon. Limnol Oceanogr 2:70-76

Ellenberg H (1958) Wald oder steppe? Die natürliche pflanzendecke der Anden Perus. Umschau 1958:645-681

Faegri K, Iversen J (1989) Textbook of pollen analysis. Wiley, New York (Fourth edition by K Faegri, PE Kaland, and K Krzywinski)

Fazlullin S, Ushakov S, Shuvalov R, Aoki M, Nikolaeva A, Lupikina E (2000) The 1996 subaqueous eruption at Academii Nauk volcano (Kamchatka) and its effects on Karymsky lake. J Volcanol Geotherm Res 97:181-193

Gosling WD, Bush MB, Hanselman HA, Chepstow-Lusty A (2008) Glacial-interglacial changes in moisture balance and the impact on vegetation in the southern hemisphere tropical Andes (Bolivia/Peru). Palaeogeogr Palaeoclimatol Palaeoecol 259:35-50

Haberyan KA (1998) The effect of volcanic ash influx on the diatom community of Lake Tanganyika, East Africa. Trans MO Acad Sci 32:102-105

Hall ML, Robin C, Beate B, Mothes P, Monzier M (1999) Tungurahua volcano, Ecuador: structure, eruptive history and hazards. J Volcanol Geotherm Res 91:1-21
Hall ML, Samaniego P, Le Pennec JL, Johnson JB (2008) Ecuadorian Andes volcanism: a review of Late Pliocene to present activity. J Volcanol Geotherm Res 176:1-6

Hall ML, Mothes P, Samaniego P, Militzer A, Beate B, Ramón P, Robin C (2017) Antisana volcano: a representative andesitic volcano of the eastern cordillera of Ecuador: petrography, chemistry, tephra and glacial stratigraphy. J South Am Earth Sci 73:50-64

Harling G (1979) The vegetation types of Ecuador: a brief survey. In: Larsen K, HolmNielsen LB (eds) Tropical botany. Academic, London, pp 165-174

Heinrichs ML, Walker IR, Mathewes RW, Hebda RJ (1999) Holocene chironomid-inferred salinity and paleovegetation reconstruction from Kilpoola Lake, British Columbia. Geogr Phys Quat 53:211

Hickman M, Reasoner MA (1994) Diatom responses to late Quaternary vegetation and climate change, and to deposition of two tephras in an alpine and sub-alpine lake Yoho National Park, British Columbia. J Paleolimn 11:173-188

Hijmans RJ, Cameron SE, Parra JL, Jones PG, Jarvis A (2005) Very high resolution interpolated climate surfaces for global land areas. Int J Climatol 25:1965-1978

Hodgson D, McDonald JL, Hosken DJ (2015) What do you mean, 'resilient'? Trends Ecol Evol 30:503-506

Hooghiemstra H (1984) Vegetational and climatic history of the high plain of Bogotá, Colombia. Dissertationes Botanicae, 79. J. Cramer, Vaduz, pp 1-368

Hooghiemstra H, van Geel B (1998) World list of Quaternary pollen and spore atlases. Rev Palaeobot Palynol 104:157-182

Jørgensen PM, León-Yánez S (eds) (1999) Catalogue of the vascular plants of Ecuador. Missouri Botanical Garden Press, St. Louis

Kessler M (1995) Present and potential distribution of Polylepis (Rosaceae) forests in Bolivia. In: Churchill SP, Balslev H, Forero E, Luteyn JL (eds) Biodiversity and conservation of neotropical montane forests. New York Botanical Garden, New York, pp 281-294

Kurenkov I (1966) The influence of volcanic ashfall on biological processes in a lake. Limnol Oceanogr 11:426-429

Le Bas MJ, Le Maitre RW, Streckeisen A, Zanettin B (1986) A chemical classification of volcanic rocks based on the total alkali-silica diagram. J Petrol 27:745-750

Le Pennec J-L, Jaya D, Samaniego P, Ramón P, Moreno Yánez S, Egred J, van der Plicht J (2008) The AD 1300-1700 eruptive periods at Tungurahua volcano, Ecuador, revealed by historical narratives, stratigraphy and radiocarbon dating. J Volcanol Geotherm Res 176:70-81

Le Pennec J-L, de Saulieu G, Samaniego P, Jaya D, Gailler L (2013) A devastating plinian eruption at Tungurahua volcano reveals formative occupation at $\sim 1100 \mathrm{cal} \mathrm{BC}$ in central Ecuador. Radiocarbon 55:1199-1214

Livingstone DA (1955) A lightweight piston sampler for lake sediments. Ecology 36:137-139

Lotter AF, Birks HJB, Zolitschka B (1995) Late-glacial pollen and diatom changes in response to two different environmental perturbations: volcanic eruption and Younger Dryas cooling. J Paleolimnol 14:23-47

Matthews-Bird F, Brooks SJ, Holden PB, Montoya E, Gosling WD (2016a) Inferring late-Holocene climate in the Ecuadorian Andes using a chironomid-based temperature inference model. Clim Past 12:1263-1280 
Matthews-Bird F, Gosling WD, Coe A, Bush M, Mayle FE, Axford Y, Brooks SJ (2016b) Environmental controls on the distribution and diversity of lentic Chironomidae (Insecta: Diptera) across an altitudinal gradient in tropical South America. Ecol Evol 6:91-112

Michelutti N, Lemmen JL, Cooke CA, Hobbs WO, Wolfe AP, Kurek J, Smol JP (2016) Assessing the effects of climate and volcanism on diatom and chironomid assemblages in an Andean lake near Quito, Ecuador. J Limnol 75:274-285

Montoya E, Rull V, van Geel B (2010) Non-pollen aplynomorphs from surface sediments along an altitudinal transect of the Venezuelan Andes. Palaeogeogr Palaeoclimatol Palaeoecol 297:169-183

Mothes P, Hall ML (2008) The plinian fallout associated with Quilotoa's 800 yr BP eruption, Ecuadorian Andes. J Volcanol Geotherm Res 176:56-69

Oksanen J, Guillaume Blanchet FRK, Legendre P, Minchin PR, O'Hara BR, Simpson GL, Solymos P, Henry M, Stevens H, Wagner H (2013) Vegan: community ecology package. R package version 2.0-10

Pinder LC (1986) Biology of freshwater Chironomidae. Annu Rev Entomol 31:1-23

Porinchu DF, Macdonald GM (2003) The use and application of freshwater midges (Chironomidae: Insecta: Diptera) in geographical research. Prog Phys Geogr 27:378-422

Prat N, Rieradevall M, Acosta R, Villamarín C (2011) Las Larvas de Chironomidae (Diptera) de Los ríos Altoandinos de Ecuador y Perú, Clave para la determinación de los géneros

Rademaker K, Hodgins G, Moore K, Zarrillo S, Miller C, Bromley GRM, Leach P, Reid DA, Yépez Álvarez W, Sandweiss DH (2014) Paleoindian settlement of the highaltitude Peruvian Andes. Science 346:466-469

Schulz R, Bundschuh M, Gergs R, Brühl CA, Diehl D, Entling MH, Fahse L, Frör O, Jungkunst HF, Lorke A, Schäfer RB, Schaumann GE, Schwenk K (2015) Review on environmental alterations propagating from aquatic to terrestrial ecosystems. Sci Total Environ 538:246-261

Seddon AWR, Froyd CA, Witkowski A, Willis KJ (2014) A quantitative framework for analysis of regime shifts in a Galápagos coastal lagoon. Ecology 95:3046-3055

Self AE, Klimaschewski A, Solovieva N, Jones VJ, Andrén E, Andreev AA, Hammarlund D, Brooks SJ (2015) Holocene environmental changes inferred from a mountain lake in central Kamchatka. Glob Planet Change 134:67-81

Shoji S, Yamada I, Kurashima K (1981) Mobilities and related factors of chemical-elements in the topsoils of andosols in Tohoku, Japan. 2. Chemical and mineralogical composition of size fractions and factors influencing the mobilities of major chemical-elements. Soil Sci 132:330-346

Telford JR, Lamb FH (1999) Groundwater-mediated response to holocene climatic change recorded by the diatom stratigraphy of an Ethiopian Crater Lake. Quat Res 52:63-75

Telford RJ, Barker P, Metcalfe S, Newton A (2004) Lacustrine responses to tephra deposition: examples from Mexico. Quat Sci Rev 23:2337-2353

Thienemann A (1922) Die beiden Chironomusarten der Tiefenfauna der norddeutschen Seen. Ein hydrobiologisches problem. Arch Hydrobiol 13:609-646

Trivinho-Strixino S (2011) Larvas de Chironomidae guia de Identificacao. Universidade Federale de Sao Carlos, Departmento de Hidrobiologia, Labaratorio de Entomologia Aquatica. Sao Carlos, pp 371

Wiederholm T (1983) Chironomid of the Holarctic region. Keys and diagnosis. Part 1. Larvae., Entomologica Scandinavica Supplement 19

Williams JJ, Brooks SJ, Gosling WD (2012) Response of chironomids to late Pleistocene and Holocene environmental change in the eastern Bolivian Andes. J Paleolimn 48:485-501

Zielinski GA (2000) Use of paleo-records in determining variability within the volcanism-climate system. Quat Sci Rev 19:417-438 